\title{
Enhanced syntrophic propionate degradation and methane production by granular activated carbon in AnSBR
}

\author{
Yiyang Fan ${ }^{1}$, Qiyi Chen ${ }^{1}$, Han Yan ${ }^{1}$, and Jianzheng $\mathrm{Li}^{1 *}$ \\ ${ }^{1}$ School of Environment, State Key Laboratory of Urban Water Resource and Environment, Harbin Institute of Technology, 73 Huanghe \\ Road, Harbin 150090, China
}

\begin{abstract}
Syntrophic degradation of propionate has been regarded as a limiting factor for methane formation in anaerobic digestion (AD) processes, due to its easier production but harder degradation than other volatile fatty acids. In the present study, $20 \mathrm{~g} / \mathrm{L}$ granular activated carbon (GAC) was introduced into an anaerobic sequence batch reactor (AnSBR) and the enhancement of propionate degradation and methane production was evaluated with another AnSBR without GAC as a control. Inoculated with the same excess activated sludge, both AnSBRs were synchronously started up at $35{ }^{\circ} \mathrm{C}$ with the fed propionate increased gradually from the initial $340 \mathrm{mg} / \mathrm{L}$ to the final $1700 \mathrm{mg} / \mathrm{L}$. The results showed that the introduction of GAC made the AnSBR get steady state 6 days earlier. With the fed propionate of about $1700 \mathrm{mg} / \mathrm{L}$ in the steady state, the average specific methane production and biomass was enhanced from 0.20 to $0.25 \mathrm{~L} / \mathrm{L} \cdot \mathrm{d}$, and 7.72 to $7.96 \mathrm{~g} / \mathrm{L}$, respectively, by the introduced GAC. The results suggested that the GAC had functioned in stimulating microbial growth and enhancing direct interspecies electron transfer between hydrogen-producing acetogens and methanogens, which had resulted in the enhanced propionate degradation and methane production.
\end{abstract}

\section{Introduction}

It is known that propionate fermentation in anaerobic digestion (AD) processes is easier occurred with more energy production than other acidogenesis such as the fermentation of butyrate, acetate and ethanol as illustrated as Eq. (1) to Eq. (4), respectively [1].

$\mathrm{C}_{6} \mathrm{H}_{12} \mathrm{O}_{6}+2 \mathrm{H}_{2} \rightarrow 2 \mathrm{CH}_{3} \mathrm{CH}_{2} \mathrm{COOH}+2 \mathrm{H}_{2} \mathrm{O}$

$$
\triangle G_{0}{ }^{\prime}=-279.4 \mathrm{~kJ} / \mathrm{mol}
$$

$\mathrm{C}_{6} \mathrm{H}_{12} \mathrm{O}_{6} \rightarrow \mathrm{CH}_{3} \mathrm{CH}_{2} \mathrm{CH}_{2} \mathrm{COOH}+2 \mathrm{H}_{2}+2 \mathrm{CO}_{2}$

$$
\triangle G_{0}{ }^{\prime}=-254.0 \mathrm{~kJ} / \mathrm{mol}
$$

$\mathrm{C}_{6} \mathrm{H}_{12} \mathrm{O}_{6}+2 \mathrm{H}_{2} \mathrm{O} \rightarrow 2 \mathrm{CH}_{3} \mathrm{COOH}+4 \mathrm{H}_{2}+2 \mathrm{CO}_{2}$

$$
\triangle G_{0}{ }^{\prime}=-206.0 \mathrm{~kJ} / \mathrm{mol}
$$

$\mathrm{C}_{6} \mathrm{H}_{12} \mathrm{O}_{6} \rightarrow 2 \mathrm{CH}_{3} \mathrm{CH}_{2} \mathrm{OH}+2 \mathrm{CO}_{2}$

$$
\triangle G_{0}{ }^{\prime}=-164.8 \mathrm{~kJ} / \mathrm{mol}
$$

On the other hand, among the produced volatile fatty acids (VFAs, except acetate) and ethanol, propionate is the most difficult one to be further converted to acetate and $\mathrm{H}_{2} / \mathrm{CO}_{2}$ by hydrogen-producing acetogens (HPAs) prior to methanogenesis, as expressed as the equations from Eq. (5) to Eq. (7) [2, 3].

$\mathrm{CH}_{3} \mathrm{CH}_{2} \mathrm{COOH}+2 \mathrm{H}_{2} \mathrm{O} \rightarrow \mathrm{CH}_{3} \mathrm{COOH}+3 \mathrm{H}_{2}+\mathrm{CO}_{2}$ $\triangle G_{0}{ }^{\prime}=+76.1 \mathrm{~kJ} / \mathrm{mol}$

$\mathrm{CH}_{3} \mathrm{CH}_{2} \mathrm{CH}_{2} \mathrm{COOH}+2 \mathrm{H}_{2} \mathrm{O} \rightarrow 2 \mathrm{CH}_{3} \mathrm{COOH}+2 \mathrm{H}_{2}$

$$
\triangle G_{0}{ }^{\prime}=+48.1 \mathrm{~kJ} / \mathrm{mol}
$$

$\mathrm{CH}_{3} \mathrm{CH}_{2} \mathrm{OH}+\mathrm{H}_{2} \mathrm{O} \rightarrow \mathrm{CH}_{3} \mathrm{COOH}+2 \mathrm{H}_{2}$

$$
\triangle G_{0}{ }^{\prime}=+19.2 \mathrm{~kJ} / \mathrm{mol}
$$

Obviously, the syntrophic degradation of propionate

\footnotetext{
* Corresponding author: jianzhengli@hit.edu.cn
}

is thermodynamic-uncomfortable under standard conditions. Thus, anaerobic oxidation of propionate has been regarded as a limiting factor for methane formation in $\mathrm{AD}$ processes [4].

It has been reported that the poor electron transfer via hydrogen as electron carrier or so-called interspecies hydrogen transfer (IHT) should be responsible for the inefficient propionate conversion in AD processes [5]. Therefore, direct interspecies electron transfer (DIET) is presented as an alternative way to enhance the electrons transfer between acetogens and methanogens [6]. Conductive carbon materials, such as activated carbon, biochar, carbon cloth and carbon filter etc, have been introduced to enhance the methane production of AD [710]. As a common AD process, anaerobic sequence batch reactor (AnSBR) has been widely practiced in engineering, but little information about the effect of conductive carbon materials on the syntrophic degradation of propionate in AnSBR could be collected up to now.

In the present research work, two lab-scale AnSBRs with or without the introduction of granular activated carbon (GAC) were constructed, respectively. Inoculated with the same excess activated sludge, both of the AnSBRs were synchronously started up at $35^{\circ} \mathrm{C}$ with the fed propionate increased gradually from the initial 340 $\mathrm{mg} / \mathrm{L}$ to the final $1700 \mathrm{mg} / \mathrm{L}$. Based on the performance of the two AnSBRs, the enhancement of propionate degradation and methane production was evaluated by comparison. 


\section{Materials and methods}

\subsection{Reactors and their operation}

Two lab-scale AnSBRs were constructed with the same 1 $\mathrm{L}$ glass bottle, respectively. One of the reactors was loaded with $20 \mathrm{~g} / \mathrm{L}$ GAC (10-24 mesh, Aladdin, China), while with the other one as a control without GAC. Inoculated with seed sludge, propionate solution was fed into the reactors to obtain a reaction volume of $0.6 \mathrm{~L}$, respectively. Then each of the reactors was sealed with rubber plug. Two glass tubes were installed through the plug for collecting biogas and feeding/discharging the supernatant in the reactor. Both of the AnSBRs were synchronously operated in an air bath vibrator (3BGH2020, Shanghai Boxun) at $35^{\circ} \mathrm{C}$ and $130 \mathrm{rpm}$. Both reactors were continuously performed for 33 days which was divided into three stages with $72 \mathrm{~h}$ (Stage 1), $48 \mathrm{~h}$ (Stage 2) and $24 \mathrm{~h}$ (Stage 3) as an operating cycle, respectively. Each of the cycles included $5 \mathrm{~min}$ for feeding $(0.3 \mathrm{~L}), 20 \mathrm{~min}$ for settlement and $5 \mathrm{~min}$ for discharging $(0.3 \mathrm{~L})$.

Excess activated sludge collected from a local municipal wastewater treatment plant (Harbin, China) was anaerobically stood for 14 days at $25^{\circ} \mathrm{C}$ and then used to inoculated the AnSBRs. The initial biomass in the reactors was almost the same of about $7.00 \mathrm{~g} / \mathrm{L}$ in terms of mixed liquor volatile suspended solid (MLVSS).

Feed into the AnSBRs was sodium propionate solution including per liter (1/L): $0.11 \mathrm{~g} \mathrm{~K}_{2} \mathrm{HPO}_{4}, 0.17 \mathrm{~g}$ $\mathrm{KH}_{2} \mathrm{PO}_{4}, 0.30 \mathrm{~g} \mathrm{NH}_{4} \mathrm{Cl}$ and $4.00 \mathrm{~g} \mathrm{NaHCO}$. The propionate in feed was gradually increased from the initial 340 to $1700 \mathrm{mg} / \mathrm{L}$ by the end of Stage 2. All through the 33-days operation, the feed was adjusted with $1.0 \mathrm{~mol} / \mathrm{L} \mathrm{NaOH}$ and $\mathrm{HCl}$ solution to get a constant $\mathrm{pH}$ of 7.50 .

\subsection{Analytical methods}

Biomass in terms of MLVSS was determined following the standard methods [11]. $\mathrm{pH}$ was measured by a $\mathrm{pH}$ meter (DELTA 320, Mettler Toledo). VFAs were determined on a gas chromatograph (Model SP6890, Shandong Lunan Instrument Factory, China) which was equipped with the RTX-Stabilwax glass column (30 $\mathrm{m} \times$ $0.32 \mathrm{~mm} \times 1 \mathrm{um}$ ) and the flame ionization detector (FID) [12]. Biogas produced in each of the operating cycles was collected into a $1 \mathrm{~L}$ gas bag and then quantified with a $100 \mathrm{~mL}$ glass syringe. Volume fraction of methane in the collected biogas was determined on another gas chromatograph (SP-6800A, Shandong Lunan Instrument Factory, China) which was fitted with a 2-m stainless column packed with Porapak. Q (100 to 180 mesh) and a thermal conductivity detector (TCD) [12].

\section{Results and discussion}

As shown in Fig. 1, the effluent $\mathrm{pH}$ of the AnSBR loaded with GAC and the AnSBR without GAC was relatively stable with an average of 7.91 and 7.88 throughout the 33-days operation, respectively, though the propionate in influent was gradually increased from 340 to $1700 \mathrm{mg} / \mathrm{L}$. It was thought that the exhaustion of propionate was responsible for the slightly higher $\mathrm{pH}$ of effluent than that of influent. The reciprocal metabolic process between propionate degradation bacteria and methanogens is easily affected by $\mathrm{pH}$ value. Lower $\mathrm{pH}$ will induce the release of molecular propionic acid in reaction system, and the excessive molecular propionic acid would lead to the reaction stagnation by damaging bacteria [13]. Therefore, the weakly alkaline condition achieved in this study was favorable for the growth and metabolism both of syntrophic propionate degradation bacteria and methanogens [12].

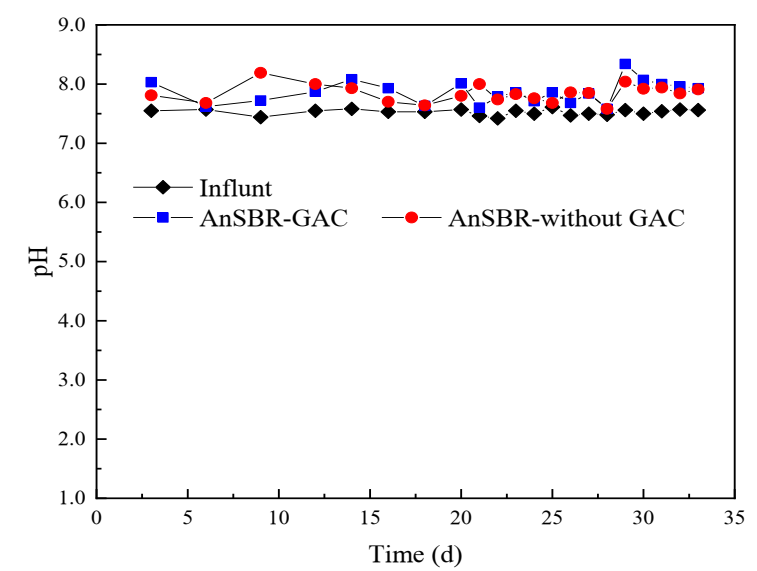

Fig. 1. Influent and effluent $\mathrm{pH}$ in the two AnSBRs with or without the introduction of GAC, respectively

The syntrophic degradation of propionate in the two reactors was illustrated in Fig. 2. The results showed that only $31.4 \%$ propionate had been degraded without the introduction of GAC in the first operating cycle with the time of $72 \mathrm{~h}$. On the contrary, almost all of the fed propionate in the AnSBR loaded with $20 \mathrm{~g} / \mathrm{L} \mathrm{GAC}$ was exhausted within the same operating cycle. The results confirmed that the introduced GAC had obviously enhanced the syntrophic degradation of propionate, which would speed up the start-up process of the AnSBR [14]. However, propionate had not been detected any more from the effluent of both the AnSBRs since the $6^{\text {th }}$ day, though the operating cycle was shortened to $24 \mathrm{~h}$ along with the propionate in influent was increased to $1700 \mathrm{mg} / \mathrm{L}$ stage by stage. The results indicated that the inoculated sludge in the AnSBR without GAC had also been acclimatized since the $6^{\text {th }}$ day. 


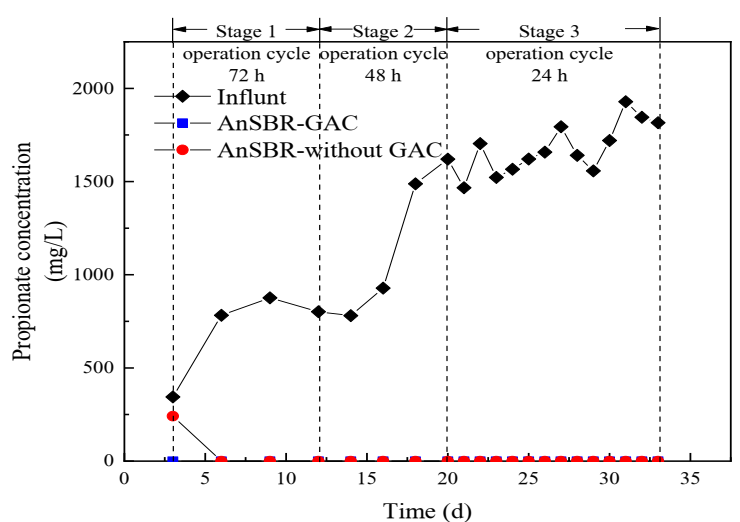

Fig. 2. Propionate in the two AnSBRs with or without the introduction of GAC, respectively

Fig. 3 illustrated the performance of both the AnSBRs in specific methane production. The results showed that a steady stage for specific methane production had been obtained in the AnSBR loaded with GAC since the $21^{\text {st }}$ day. However, the steady state was not observed until the $27^{\text {th }}$ day. The results suggested that the introduction of GAC had significantly speed up the start-up process of the AnSBR. It was found that, with the longest operating cycle of $72 \mathrm{~h}$, no obvious difference in specific methane production was found between the AnSBRs with or without the introduction of GAC. However, when the operating cycle was shortened to $48 \mathrm{~h}$ in Stage 2 with the propionate of about 1100 $\mathrm{mg} / \mathrm{L}$ in feed, the specific methane production in the AnSBR loaded with GAC averaged $0.11 \mathrm{~L} / \mathrm{L} \cdot \mathrm{d}$ which was much more than that of $0.04 \mathrm{~L} / \mathrm{L} \cdot \mathrm{d}$ in the AnSBR without GAC. Since the operating cycle was further shortened to $24 \mathrm{~h}$ in Stage 3 with the propionate of about $1700 \mathrm{mg} / \mathrm{L}$ in the feed, the specific methane production in the AnSBR loaded with GAC was enhanced to about $0.25 \mathrm{~L} / \mathrm{L} \cdot \mathrm{d}$. On the other hand, the specific methane production in the AnSBR without GAC averaged 0.20 $\mathrm{L} / \mathrm{L} \cdot \mathrm{d}$ in the last 7 days (the steady stage). Also, the methane convert ratio in the AnSBR with GAC were about $51.4 \%$ in the steady stage, higher than that in the AnSBR without GAC (Fig, 4). The results indicated that

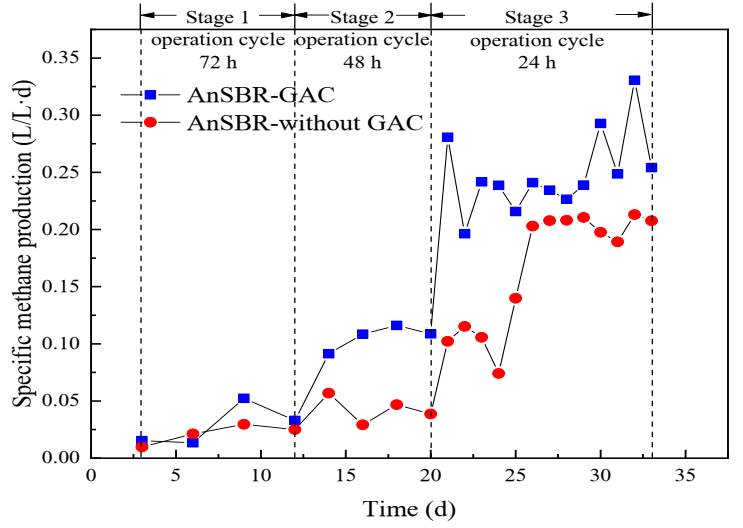

Fig. 3. Specific methane production in the two AnSBRs with or without the introduction of GAC, respectively

the introduction of GAC had not only speed up the startup process but also enhanced the methane formation from propionate in the AnSBR. This is probably due to that the addition of GAC reduces the Gibbs free energy of propionate metabolism with the electron transfer

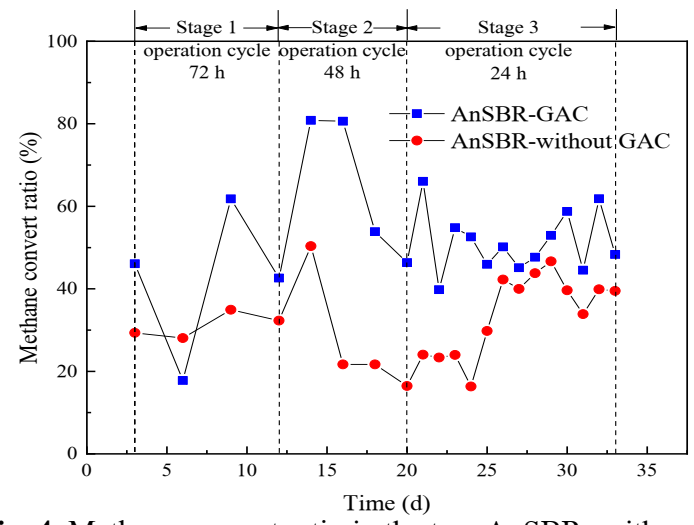

Fig. 4. Methane convert ratio in the two AnSBRs with or without the introduction of GAC, respectively

changing from IHT to DIET [15], which is conducive to the proliferation of bacteria. At the same time, the DIET process mediated by activated carbon avoids the loss of hydrogen and formate used as intermediate electron carriers [16], leading to more electrons participate in the process of reducing carbon dioxide to methane. Therefore, the methane production rate was significantly improved by the additional GAC.

The biomass in the AnSBR loaded with GAC was increased from the initial 7.00 to $7.96 \mathrm{~g} / \mathrm{L}$ by the end of the 33-days operation process, while with the biomass in the AnSBR without GAC increased to $7.72 \mathrm{~g} / \mathrm{L}$. Obviously, the introduced GAC was also favorable for the population growth of anaerobic sludge in the AnSBR. It was thought that the porous structure of GAC had allowed syntrophic propionate degradation bacteria and

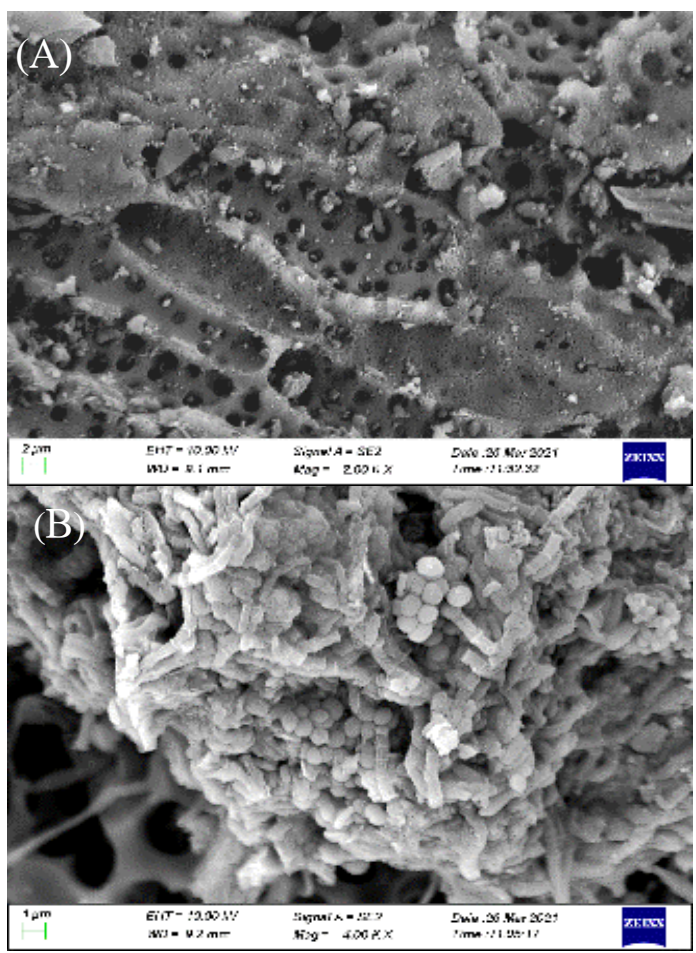

Fig. 5. The surface-characteristic of GAC (A) and various microbial populations on the surface of GAC after operation (B) in the AnSBR

methanogens to gather and thrived together on the surface (Fig. 5A). Over time, SEM showed that biofilm 
would certainly be construct on the surface of GAC, by which more biomass was kept in the AnSBR (Fig. 5B) [17]. Also, it was observed that long bamboo nodular microorganisms (e.g. Methanothrix) were attached to the surface of GAC, and tightly intertwined with some spherical (e.g. Methanosarcina) and ellipsoid microorganisms. Methanothrix and Methanosarcina can both produce methane from the reduction of carbon dioxide by accepting electrons through the DIET pathway $[18,19]$. These results indicated that a DIET pathway between methanogens and propionate degradation bacteria was likely to be established with the additional GAC.

It is known that GAC can function as a precursor to DIET among various functional microbial populations in AD process because of its high electrical conductivity [20]. In fact, GAC can act as not only an electron accepter to endorse DIET, but also an electron donor pool for various biochemical reactions [21]. It has been reported that the DIET can be $10^{6}$ times quicker than IHT [22], resulting in an excellent efficiency in VFAs degradation and methane production. In the present research work, the introduction of GAC had not only speed up the start-up process of AnSBR, but also remarkably enhanced the specific methane production and biomass. With the propionate averaged $1700 \mathrm{mg} / \mathrm{L}$ in feed and an operating cycle of $24 \mathrm{~h}$, the specific methane production was enhanced by 1.25 times because of the introduction of $20 \mathrm{~g} / \mathrm{L} \mathrm{GAC}$, while with the biomass increased from 7.72 to $7.96 \mathrm{~g} / \mathrm{L}$. However, the DIET in the present AnSBR was only a pretty-astute deduction. Therefore, more evidences should be collected to confirm the deduction in the future investigation.

\section{Conclusions}

Two AnSBRs was constructed and operated synchronously to evaluated the effect of GAC on the syntrophic propionate degradation and methane production. Based on the experiments, the following conclusions are obtained.

(1) The introduction of GAC made the AnSBR get steady state 6 days earlier.

(2) With the propionate averaged $1700 \mathrm{mg} / \mathrm{L}$ in feed and an operating cycle of $24 \mathrm{~h}$, the specific methane production in the AnSBR had been increased by 1.25 times because of the introduction of GAC.

(3) Biomass in the AnSBR was also increased from 7.72 to $7.96 \mathrm{~g} / \mathrm{L}$ by the introduced GAC.

(4) The DIET induced by the GAC was suggested as the key reason for the enhanced $\mathrm{AD}$ process in the AnSBR.

\section{Acknowledgment}

The authors acknowledge the financial support from the National Natural Scientific Foundation of China (51778171).

\section{References}

1. N.M.C. Saady. International Journal of Hydrogen Energy, 38, 13172-13191 (2013)

2. A.J.M. Stams, D.Z. Sousa, R. Kleerebezem, C.M. Plugge. Water Sci Technol, 66, 352-362 (2012)

3. J. Li, H. Yan, Q. Chen, J. Meng, J. Li, Y. Zhang, A. Kumar Jha. Bioresource Technol, 124972 (2021)

4. K. Glissmann, R. Conrad. Fems Microbiol Ecol, 31, 117-126 (2000)

5. B. Schink, D. Montag, A. Keller, N. Muller. Env Microbiol Rep, 9, 189-202 (2017)

6. W. Wang, D.J. Lee. Bioresource Technol, 330, 14 (2021)

7. M.S. Romero-Guiza, J.J. Vila, J. Mata-Alvarez, J.M. Chimenos, S. Astals. Renew Sust Energ Rev, 58, 1486-1499 (2016)

8. Q.J. Feng, Y.Q. Lin. Renew Sust Energ Rev, 77, 1272-1287 (2017)

9. J.S. Zhang, W.Q. Zhao, H.W. Zhang, Z.J. Wang, C.F. Fan, L.H. Zang. Bioresource Technol, 266, 555-567 (2018)

10. S.O. Masebinu, E.T. Akinlabi, E. Muzenda, A.O. Aboyade. Renew Sust Energ Rev, 103, 291-307 (2019)

11. A.P.H.A. APHA, AWWA and WPCF, Washington DC, (2012)

12. Y.P. Zhang, J.Z. Li, F.Q. Liu, H. Yan, J.L. Li. Environ Sci Pollut R, 25, 12434-12443 (2018)

13. H. Yuan, N. Zhu. Renewable and Sustainable Energy Reviews, 58, 429-438 (2016)

14. W.X. Sun, S.F. Fu, R. Zhu, Z.Y. Wang, H. Zou, Y. Zheng. Bioresource Technol, 313, 8 (2020)

15. R. Lin, J. Cheng, L. Ding, J.D. Murphy. Chem Eng J, 350, 681-691 (2018)

16. D.R. Lovley. Rev Environ Sci Bio-Technol, 10, 101105 (2011)

17. S.Q. Aziz, H.A. Aziz, M.S. Yusoff, M.J.K. Bashir. J Hazard Mater, 189, 404-413 (2011)

18. A.E. Rotaru, P.M. Shrestha, F.H. Liu, M. Shrestha, D. Shrestha, M. Embree, K. Zengler, C. Wardman, K.P. Nevin, D.R. Lovley. Energ Environ Sci, 7, 408415 (2014)

19. A.E. Rotaru, P.M. Shrestha, F. Liu, B. Markovaite, S. Chen, K.P. Nevin, D.R. Lovley. Appl Environ Microb, 80, 4599-4605 (2014)

20. R.C. Lin, J. Cheng, J.B. Zhang, J.H. Zhou, K.F. Cen, J.D. Murphy. Bioresource Technol, 239, 345-352 (2017)

21. F.H. Liu, A.E. Rotaru, P.M. Shrestha, N.S. Malvankar, K.P. Nevin, D.R. Lovley. Energ Environ Sci, 5, 8982-8989 (2012)

22. G. Capson-Tojo, R. Moscoviz, D. Ruiz, G. SantaCatalina, E. Trably, M. Rouez, M. Crest, J.P. Steyer, N. Bernet, J.P. Delgenes et al. Bioresource Technol, 260, 157-168 (2018) 